This PDF is a selection from an out-of-print volume from the National Bureau of Economic Research

Volume Title: International Taxation and Multinational Activity

Volume Author/Editor: James R. Hines, Jr.

Volume Publisher: University of Chicago Press

Volume ISBN: 0-226-34173-9

Volume URL: http://www.nber.org/books/hine00-1

Conference Date: November 14-15, 1997

Publication Date: January 2000

Chapter Title: Does Corruption Relieve Foreign Investors of the Burden of Taxes and Capital Controls?

Chapter Author: Shang-Jin Wei

Chapter URL: http://www.nber.org/chapters/c10720

Chapter pages in book: (p. 73 - 88) 


\title{
Does Corruption Relieve Foreign Investors of the Burden of Taxes and Capital Controls?
}

\author{
Shang-Jin Wei
}

\subsection{Introduction}

This paper studies the effects of several irritants to foreign direct investment, including taxes, capital controls, and corruption. Moreover, it investigates whether corruption provides international investors relief from the taxes and capital controls they face in host countries.

A large number of excellent papers study the effect of taxation on international direct investment (e.g., Altshuler, Grubert, and Newlon [chap. 1 in this volume], and papers in Feldstein, Hines, and Hubbard 1995). Corruption has recently attracted attention not only from academics but also from international financial institutions, as exemplified by the IMF's decision to condition its loans to Kenya on the latter's effort to reduce corruption. Using data on outward investment from the United States, Hines (1995) found that American firms invest less in more corrupt host countries, which he interpreted as the effect of the U.S. Foreign Corrupt Practices Act. Using a sample of bilateral investment from fourteen major source countries to forty-five host countries, Wei $(1997,2000)$ found that all major source countries invest less in more corrupt countries. Later, Hines (1996) found that capital controls have a statistically significant and

Shang-Jin Wei is associate professor of public policy at Harvard University's Kennedy School of Government and a faculty research fellow of the National Bureau of Economic Research. During 1999-2000, he serves as an advisor at the World Bank on anticorruption and international capital flow issues.

The author thanks Jim Hines for providing intellectual stimulation on this project; Bernie Yeung, Joel Slemrod, and other conference participants for very helpful comments; and Jungshik Kim and Greg Dorchak for very efficient research and editorial assistance. The views in the paper are the author's and may not be shared by any organization that he is or has been associated with. 
negative effect on inward foreign investment. These papers have studied the effects of corruption and capital controls in isolation, but not in an integrated framework.

Furthermore, a separate strand in the literature (e.g., Leff 1964; Huntington 1968; Lui 1985) sees virtue in corruption. In particular, in an environment with excessive tax, severe capital control, or numerous licensing requirements, bribery allows firms to circumvent these otherwise suffocating regulatory burdens. Therefore, holding the level of tax and capital controls constant, more bribes may lead to more foreign (and domestic) investment. This argument may be characterized as a theory of "efficient grease payments." On the other hand, if regulatory burdens are endogenously chosen by the bureaucrats solely to extract rents, one may see more regulatory burdens in countries with more corruption (see Kaufmann and Wei 1999 for a formal model and some firm-level evidence). Therefore, whether corruption in a host country with high tax rates and severe capital controls is responsible for more or less foreign investment is an open question, the answer to which depends on the degree to which taxes and capital controls are erected and maintained for rent-seeking purposes. Earlier papers have not investigated possible interactions between corruption and taxation, and between corruption and capital controls. This paper tries to fill that void.

Using data over a large number of source-host pairs, this study quantifies the importance of a number of economic and noneconomic factors that may affect international direct investment. It compares these effects with those of corporate income taxation whenever possible. Most importantly, it examines whether bribery in countries with high tax rates and severe capital controls tends to encourage inward foreign direct investment.

The paper is organized as follows. Section 3.2 describes the data set. Section 3.3 discusses the statistical analyses and interpretations. Section 3.4 concludes.

\subsection{Data}

\subsubsection{Bilateral International Direct Investment}

The dependent variable is (a transformation of) bilateral stocks of foreign investment in 1991 from fourteen major source countries to forty-five host countries. The list of source countries includes the seven largest (in terms of outward direct investment) in the world: the United States, Japan, Germany, the United Kingdom, France, Canada, and Italy. The number of the host countries in the sample is constrained by the joint availability of data on tax rates, corruption levels, and capital controls. The data come from the OECD database on international direct investment (OECD 1991). 


\subsubsection{Tax}

The host countries' tax rates are 1989 values. It is worth noting that tax rates do not change very much over the 1989-91 period. The actual measure is the smaller of two numbers (whenever both are available): the statutory marginal tax rate on foreign corporations as reported by Price Waterhouse (1990), or the actual average tax rate paid by the foreign subsidiaries of U.S. firms in that country. The data on twenty-eight of the host countries are taken from Desai and Hines (1996, app. 2). The rest are obtained using the Price Waterhouse source with the able assistance of Mihir Desai.

\subsubsection{Corruption}

The empirical work in the paper utilizes two measures of corruption. The first is the Business International (BI) index, which is based on surveys from 1980 to 1983, and ranks countries from one to ten according to "the degree to which business transactions involve corruption or questionable payments." The data were provided by Paolo Mauro and were used in his 1995 paper on corruption and economic growth. The second source is the index composed by Transparency International (TI), an agency dedicated to fighting corruption worldwide. The TI index (available at http://www. transparency.de/) is an average of ten surveys by different agencies over a number of years. It has an advantage and a disadvantage relative to the BI index. On the one hand, assuming measurement errors in different surveys are independent, the averaging process of the TI index may produce smaller measurement errors in the end. On the other hand, different surveys cover different sets of countries and may use different criteria, so the ratings on different countries in the TI index may be less comparable. Fortunately, the two indexes are highly correlated (with a correlation coefficient of 0.88 ). Which index to use makes no qualitative difference for subsequent discussions; hence, later sections will report results with the BI index only.

In both original sources, the indexes are defined so that a high number means low corruption. To avoid awkwardness in interpretation, I have rescaled them so that a large number means more corruption.

\subsubsection{Capital Controls}

There are two capital control measures. The first is a survey-based measure from Business International, collected from 1980 to 1983. In the original survey, a higher number (say, ten) meant less restriction on capital account. I have rescaled the numbers so that a higher number means more restrictions. This measure is supposed to be on a one-to-ten scale, although, in the sample, the minimum and maximum are one and eight, respectively. This measure is used in Hines (1996). The second measure is 
a dummy based on IMF's Exchange Arrangements and Exchange Restrictions. The two measures have a correlation coefficient of 0.46 . This paper reports the results using only the $\mathrm{BI}$ measure.

\subsubsection{Other Data}

The GDP data come from the IMF's International Financial Statistics database. In a few cases in which GDP data are not available, GNP data are used instead.

The bilateral distance data measure the "greater circle distance" between the economic centers in source-host pairs. The dummy variable measure of linguistic ties takes the value of 1 if the source and host share a common language (either English, French, Spanish, German, Arabic, Chinese, Japanese, Portuguese, or Italian) and 0 otherwise. Both data are taken from Frankel, Stein, and Wei (1995).

Four additional potential irritants to foreign investment are (1) restrictions on foreign firms' access to domestic capital markets, (2) restrictions on their abilities to set up joint ventures with domestic firms, (3) restrictions on their abilities to bid on public sector projects, and (4) restrictions on their corporate control rights. The paper uses four binary measures (dummies) for the four irritants; they are all survey responses of subjective perceptions from the Global Competitiveness Report (World Economic Forum 1997).

Table 3.1 reports summary statistics on some of the key variables. The average corruption level (BI index) is 3.70 (on a one-to-ten scale); the average degree of capital control (BI index) is 3.31 (on a one-to-ten scale); and the average tax rate in the sample is 34 percent.

\subsection{Statistical Analyses}

One could run an ordinary least squares (OLS) specification of the following sort:

$$
\ln \left(\mathrm{FDI}_{i j}\right)=\mathrm{X}_{i j} \beta+u_{i j},
$$

where $\mathrm{FDI}_{i j}$ is the stock of foreign investment from source country $i$ to host country $j$, and $X$ is a vector of regressors, including the host country's GDP in logarithm and the distance between the source and host countries in logarithm. Experience indicates that, in analogy to the gravity specification on trade flows, the logarithmic transformation on both sides of the equation (of the dependent variable and of most of the regressors), called double-log linear specification, produces the best functional fit.

Many host countries receive no direct investment from some source countries. A serious drawback of the double-log linear specification is that observations of zero FDI are dropped by this specification. It is natural 


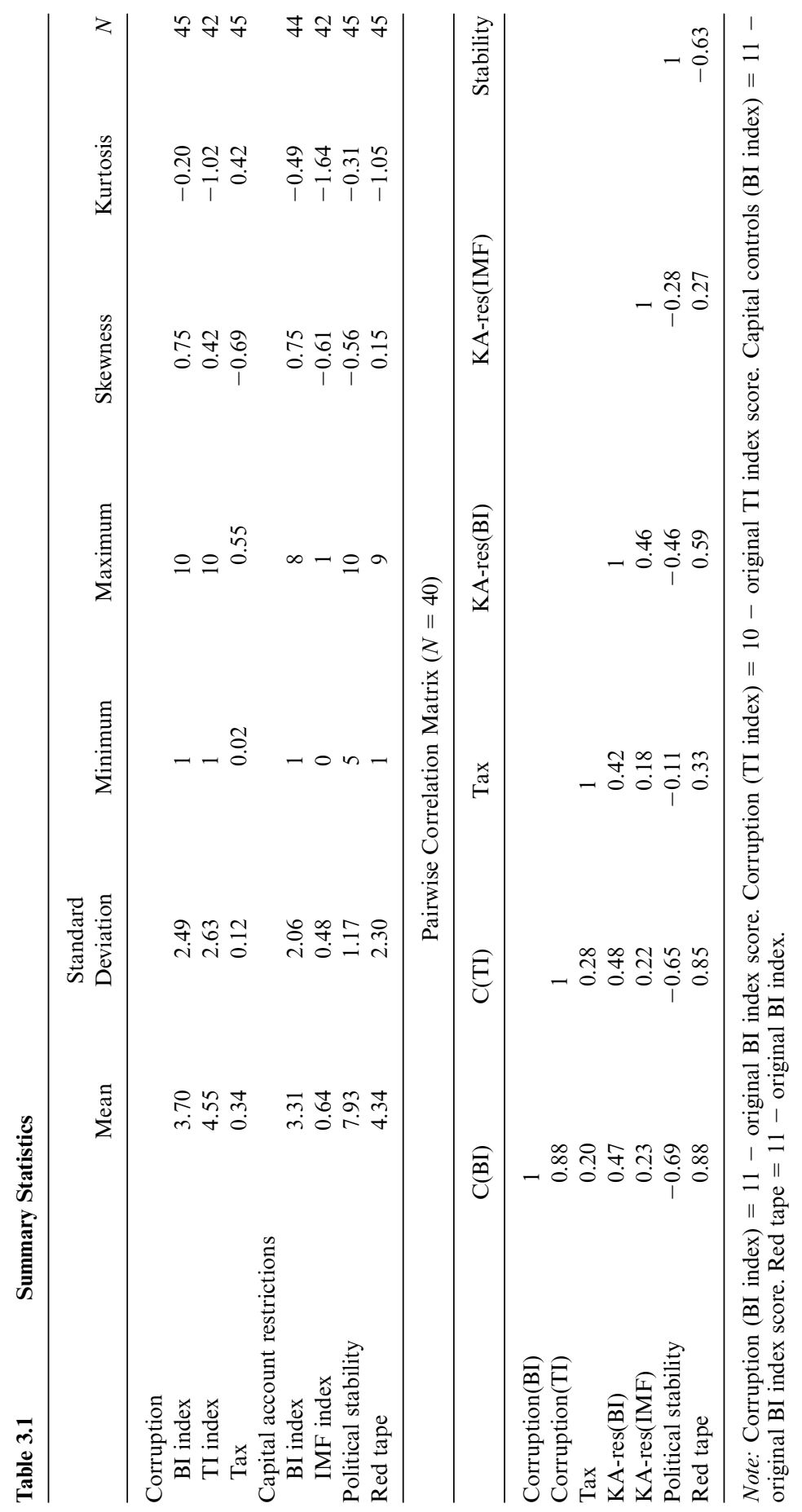


to think of using a Tobit specification to replace the OLS; but the problem there is that the simple Tobit specification conflicts with the double-log transformation, as log of zero is not defined. To deal with this problem, I employ the following specification in this paper:

$$
\begin{aligned}
\ln \left(\mathrm{FDI}_{i j}+A\right) & =X \beta+u_{i j} \quad \text { if } \quad X \beta+u_{i j}>\ln (A) \\
& =\ln (A) \quad \text { if } \quad X \beta+u_{i j} \leq \ln (A),
\end{aligned}
$$

where $A$ is a threshold parameter to be estimated, $u$ is an independently and identically distributed (i.i.d.) normal variate with mean zero and variance $\sigma^{2}$. In this specification, if $X \beta+u$ exceeds a threshold value, $\ln (A)$, source country $i$ accumulates a positive stock of investment in host country $j$; otherwise, the realized foreign investment is zero (and the desired level could be negative).

This framework is modified in subsequent implementation to become a quasi-fixed effects specification: There are source-country dummies, but no host-country dummies. The source-country dummies are intended to capture source country-specific differences in the stock of bilateral direct investment. Such differences include the sizes and levels of development of the source countries, and possibly different definitions of outward direct investment used by different source countries (under the assumption that the FDI amount under one definition is proportional to the amount under another definition plus an i.i.d. random error). Host country dummies are not included because there are no reliable measures of year-to-year variations in corruption and capital controls, which are key variables for this paper.

\subsubsection{Empirical Results: Continuous Measures}

To get some idea of the quantitative importance of corruption levels and tax rates, I have implemented a very simple specification. The two key regressors are tax rate and average corruption level (BI index). In addition, the estimating equation includes source-country dummies, host-country GDP in logarithm, distance between the source and host countries in logarithm, and a dummy indicating whether the source and host countries share a common language. The last two regressors are motivated by recent emphasis on the importance of networks in trade and investment, as in the work of Rauch (1996).

Table 3.2 presents the basic results. In column (1), which has the most parsimonious specification, both tax rate and corruption measure have negative and statistically significant coefficients. A one-step increase in corruption rating has the same negative effect on FDI as an increase in the tax rate by 4.69 percentage points $(0.09 /[0.01 \times 1.92]=4.69)$. For instance, an increase in corruption level from that of Singapore (with a $\mathrm{BI}$ corruption rating of 1 ) to that of Colombia (with a BI corruption rat- 


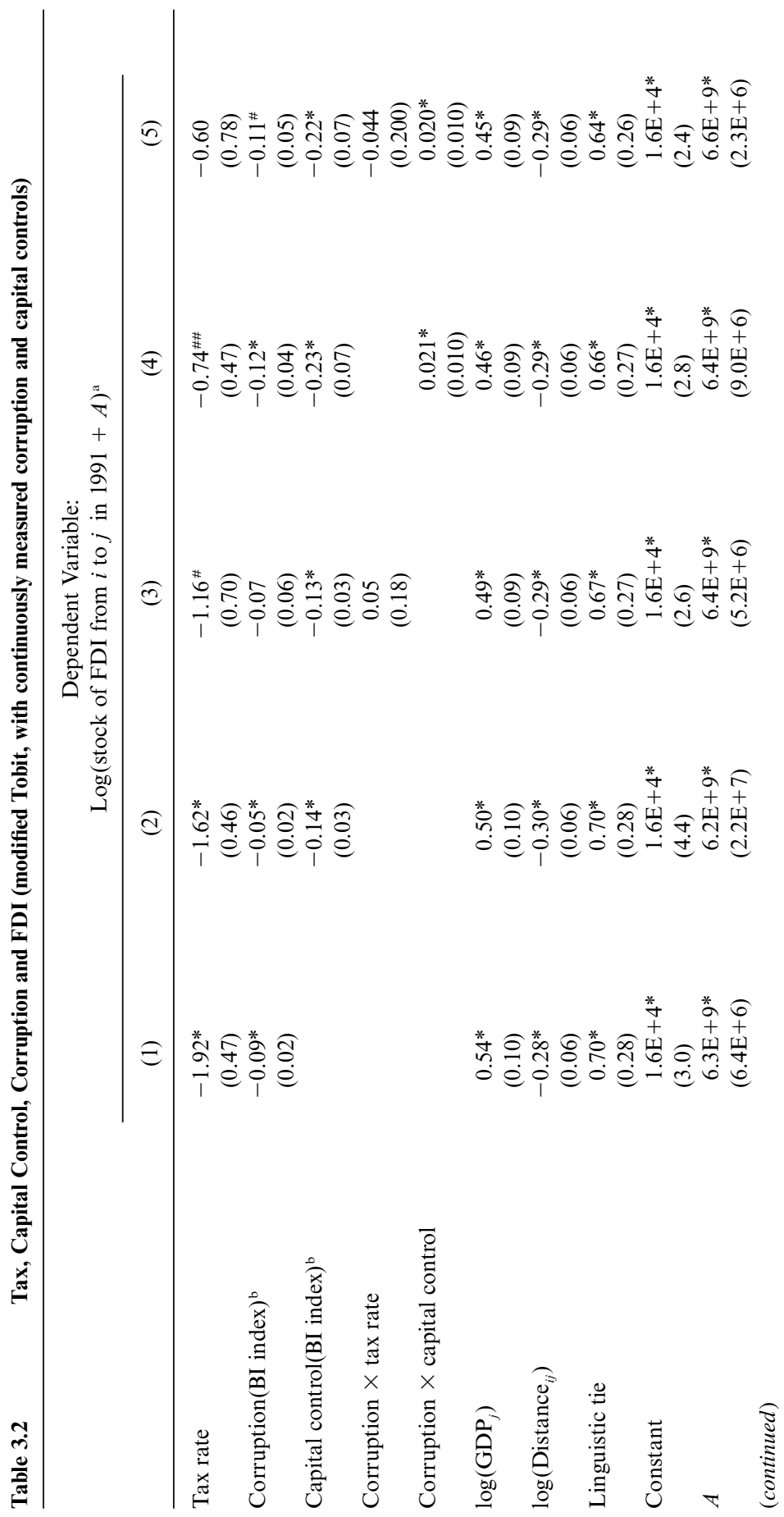




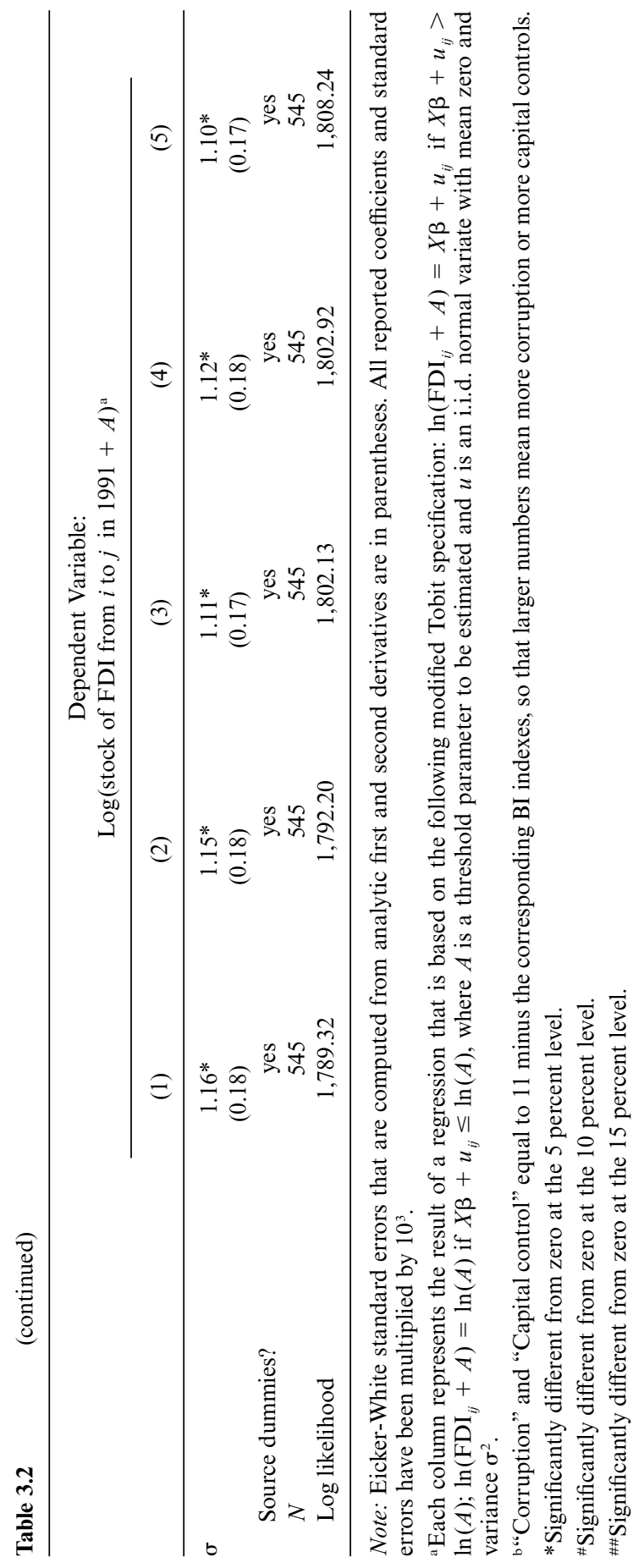


ing of 6.5) is equivalent to raising the tax rate by 25.8 percentage points $([6.5-1] \times 4.69=25.8)$. Similarly, an increase in the average corruption level from that of Singapore to that of Mexico (with a BI corruption rating of 7.25) is equivalent to raising the tax rate by 29.3 percentage points $([7.25-1] \times 4.69=29.3)$.

We note that all three control variables have statistically significant coefficients and sensible signs. A host country with a larger GDP attracts more FDI than otherwise. A host country that is closer to the source country either geographically or linguistically (or that is historically related to the source country) also attracts more inward investment than otherwise.

A measure of severity of capital controls (by the BI index) is added in column (2). This variable has a negative sign and is statistically different from zero. Because countries that impose capital controls and those that have high taxes tend to be correlated (with a correlation coefficient of 0.40 , according to table 3.1 ), the coefficient on the tax variable declines a bit (from -1.92 to -1.62 ) but remains statistically significant. Taking the point estimates literally, a one-step increase in the severity of capital controls is equivalent to raising the marginal tax rate by 13.2 percentage points $(=0.14 /[0.01 \times 1.62])$. An increase in the severity of capital controls from the Singapore level (BI index value of 1) to the Philippines level (BI index level of 4) is equivalent to raising the marginal tax rate by 39.6 percent.

So far, we have considered the effects of tax, corruption, and capital control in isolation. Again, a popular (and previously untested) argument is that bribes can sometimes function as "grease payments," helping firms by effectively reducing tax burden or evading capital controls. If the grease payment effect works in reality, then the same level of tax should be a lesser hindrance to foreign investment in countries with greater possibility of bribing officials.

Alternatively, the grease payment argument may have no merit. Kaufmann and Wei (1999) argue that regulatory burdens, such as those imposed by taxes and capital controls, may well be endogenous, implemented by corruption-prone officials in order to extract bribes. In other words, bribes might reduce taxes only in a partial equilibrium story in which the tax rate is predetermined. In a general equilibrium, however, taxes may in fact be higher in corrupt countries so that firms there do not end up paying less in taxes (or facing less severe capital controls).

We now check this possibility. We first add a new term to the regression, "Corruption $\times$ tax rate." The efficient grease theory implies that the coefficient on this interactive term should be positive. Column (3) of table 3.2 reports the regression with the new interactive term, "Corruption $\times$ tax rate." As it happens, the corresponding coefficient does not differ from zero statistically (though it is positive); hence, there is no statistical support for the grease payment argument; foreign investors' sensitivity to host tax rate does not seem to diminish as the host country gets more corrupt.

The efficient grease argument is equally applicable to capital controls, 
so that one may ask: Does greater corruption in a host country make the same degree of capital controls more tolerable to foreign investors? To investigate this question, we augment the specification in column (2) with a different interactive term, "Corruption $\times$ capital control." The result is reported as column (4) of table 3.2. The coefficient turns out to be positive and statistically significant. This means literally that the sensitivity of FDI to the severity of capital controls is indeed less for more corrupt host countries. This seems to support the grease payment hypothesis as applied to capital controls.

On the other hand, this result does not imply that foreign investors would necessarily invest more in a more corrupt host country. Consider two host countries with identical capital controls (say, capital control indexes $=4$, approximately the mean in the sample, of which the Philippines and Ecuador would be examples). If country A is more corrupt than country $\mathrm{B}$ (say, the corruption indexes are 9 and 7 , respectively), the net effect of this increment in corruption on FDI is still negative, because $(9-7) \times$ $(-0.12)+(9-7) \times 4 \times 0.021=-0.072$.

\subsubsection{Empirics: Binary Measures of Corruption and Capital Controls}

In the previous subsection, we measure capital controls and corruption on a one-to-ten scale. Because these measures come from surveys of respondents' impressions, small measurement errors can easily change the ranking of host countries. In this subsection, we eliminate the overly fine gradation of the capital control and corruption measures by constructing corresponding binary measures. Specifically, we define D(corruption) as a dummy that takes the value of 1 if the corruption index exceeds 6 , and the value of 0 otherwise. Similarly, we define $\mathrm{D}$ (cap-control) to be a dummy for countries whose capital control index exceeds $6 .{ }^{1}$

Table 3.3 replicates all the regressions in table 3.2, after replacing the ten-step measures of corruption and capital controls by their binary counterparts. In columns (1) and (2), tax, corruption, and capital control individually still have a negative and statistically significant effect on inward foreign investment. Other things being equal, foreign investors invest less in a country with higher tax, more corruption, or more severe capital controls.

The last three columns show the interactions between corruption and tax rates, and between corruption and capital controls. In column (3), where only the former interaction is shown, the coefficient on the regressor " $\mathrm{D}$ (corruption) $\times$ tax rate" is negative. As in the regressions reported in table 3.2, this finding is contrary to the hypothesis that grease payments make taxes less irritating to investors. In column (4), where the interaction term " $\mathrm{D}$ (corruption) $\times \mathrm{D}$ (cap-control)" is added alone, the coefficient on

1. Other threshold values (5 and 7) were tried and did not make a qualitative difference for the subsequent discussion. 





the term is positive but not statistically different from zero at the 10 percent level. In fact, even if one takes the point estimate as given, the estimates suggest that investors will unambiguously invest less in a more corrupt country whether that country has tight or loose capital controls. This differs from the earlier observation in table 3.2, that bribes may reduce the negative effect of capital controls on foreign investment. In other words, the earlier observation is not robust. In column (5), both interactive terms are put together in the regression. The result is essentially the same as before; there is no statistically significant support for the grease payment argument on either the effect of tax or on that of capital controls.

\subsubsection{Additional Controls}

To check for robustness with regard to our inference on the validity of the grease payment argument, I add some further control variables. The results are reported in table 3.4.

The first column of table 3.4 adds a measure of political stability in the host countries. Not surprisingly, more stable regimes attract more investment. Note that our conclusions on the interactions between corruption and tax, and between corruption and capital controls, remain true; there is no support for the grease payment argument.

The second column adds a measure of red tape or bureaucracy in the host countries. While the new variable has a negative sign, as would be consistent with one's intuition, it is not different from zero statistically.

The last column adds average hourly wage in host countries' manufacturing sectors as well as a dummy for OECD host countries. Because the wage data are available for a smaller number of countries, this change cuts down the sample size considerably. As it turns out, the OECD dummy is positive and significant: All else being equal, OECD hosts attract more FDI. The wage variable has a negative and significant coefficient; countries with lower labor costs also attract more FDI. Controlling for these effects, there is still no support for the validity of the grease payment hypothesis.

Subsequent regressions experiment with adding (1) foreign firms' access to domestic capital markets, (2) foreign firms' ability to set up joint ventures with domestic firms, (3) foreign firms' ability to bid on public sector projects, and (4) foreign firms' ability to exert corporate control rights. The four dummies are all survey responses of subjective perceptions from the 1997 Global Competitiveness Report (World Economic Forum 1997). As it happens, the four dummies are highly correlated. If all four are put into the regression, none has a coefficient statistically different from zero. Moreover, the earlier conclusions regarding the effects on FDI of tax rates, corruption levels, and capital controls, as well as their interactions, remain the same. If we add only one of the four dummies, say, foreign firms' access to domestic capital markets, this variable does have a statistically significant coefficient. Greater restrictions on access to domestic capital lead to less foreign investment. (The regression results are not reported.) 
Table 3.4 More Robustness Checks (modified Tobit, binary measures of corruption and capital controls)

\begin{tabular}{|c|c|c|c|}
\hline & \multicolumn{3}{|c|}{$\begin{array}{l}\text { Dependent Variable: } \\
\log (\text { stock of FDI from } i \text { to } j \text { in } 1991+A \text { ) }\end{array}$} \\
\hline & (1) & (2) & (3) \\
\hline Tax rate & $\begin{array}{r}-0.77^{\#} \\
(0.40)\end{array}$ & $\begin{array}{r}-0.74^{\#} \\
(0.41)\end{array}$ & $\begin{array}{r}-1.07^{*} \\
(0.45)\end{array}$ \\
\hline $\mathrm{D}$ (corruption) & $\begin{array}{c}0.76 \\
(0.70)\end{array}$ & $\begin{array}{c}0.74 \\
(0.69)\end{array}$ & $\begin{array}{l}1.11^{\#} \\
(0.07)\end{array}$ \\
\hline $\mathrm{D}$ (cap-control) & $\begin{array}{r}-0.13^{*} \\
(0.03)\end{array}$ & $\begin{array}{r}-0.12^{*} \\
(0.03)\end{array}$ & $\begin{array}{r}-0.11^{*} \\
(0.04)\end{array}$ \\
\hline $\mathrm{D}$ (corruption) $\times$ tax rate & $\begin{array}{l}-3.00^{\# \#} \\
(2.07)\end{array}$ & $\begin{array}{c}-2.89 \\
(2.03)\end{array}$ & $\begin{array}{r}-3.63^{\#} \\
(1.96)\end{array}$ \\
\hline $\mathrm{D}$ (corruption $) \times \mathrm{D}($ cap-control $)$ & $\begin{array}{c}0.056 \\
(0.043)\end{array}$ & $\begin{array}{c}0.053 \\
(0.043)\end{array}$ & $\begin{array}{c}0.044 \\
(0.046)\end{array}$ \\
\hline Political stability & $\begin{array}{l}0.10^{*} \\
(0.05)\end{array}$ & $\begin{array}{c}0.09^{\#} \\
(0.06)\end{array}$ & $\begin{array}{c}0.12^{*} \\
(0.06)\end{array}$ \\
\hline Red tape & & $\begin{array}{c}-0.01 \\
(0.03)\end{array}$ & $\begin{array}{r}-0.07^{\#} \\
(0.04)\end{array}$ \\
\hline OECD dummy & & & $\begin{array}{r}0.37^{*} \\
(0.13)\end{array}$ \\
\hline $\log \left(\right.$ wage $\left._{j}\right)$ & & & $\begin{array}{r}-0.24^{*} \\
(0.08)\end{array}$ \\
\hline $\log \left(\mathrm{GDP}_{j}\right)$ & $\begin{array}{c}0.41^{*} \\
(0.08)\end{array}$ & $\begin{array}{c}0.40^{*} \\
(0.08)\end{array}$ & $\begin{array}{c}0.40^{*} \\
(0.08)\end{array}$ \\
\hline $\log \left(\right.$ distance $\left._{i j}\right)$ & $\begin{array}{r}-0.25^{*} \\
(0.05)\end{array}$ & $\begin{array}{r}-0.25^{*} \\
(0.05)\end{array}$ & $\begin{array}{c}-0.25^{*} \\
(0.06)\end{array}$ \\
\hline Linguistic tie & $\begin{array}{r}0.60^{*} \\
(0.23)\end{array}$ & $\begin{array}{c}0.56^{*} \\
(0.28)\end{array}$ & $\begin{array}{r}0.59^{*} \\
(0.22)\end{array}$ \\
\hline Constant & $\begin{array}{l}1.6 \mathrm{E}+4^{*} \\
(2.5)\end{array}$ & $\begin{array}{l}1.6 \mathrm{E}+4^{*} \\
(2.5)\end{array}$ & $\begin{array}{l}1.6 \mathrm{E}+4^{*} \\
(2.3)\end{array}$ \\
\hline$A$ & $\begin{array}{c}7.6 \mathrm{E}+9^{*} \\
(5.7 \mathrm{E}+6)\end{array}$ & $\begin{array}{c}7.7 \mathrm{E}+9^{*} \\
(6.2 \mathrm{E}+6)\end{array}$ & $\begin{array}{r}8.5 \mathrm{E}+9^{*} \\
(4.5 \mathrm{E}+6)\end{array}$ \\
\hline$\sigma$ & $\begin{array}{c}0.96^{*} \\
(0.15)\end{array}$ & $\begin{array}{c}0.94^{*} \\
(0.15)\end{array}$ & $\begin{array}{c}0.91 * \\
(0.15)\end{array}$ \\
\hline Source dummies? & $\begin{array}{l}\text { yes } \\
545\end{array}$ & $\begin{array}{l}\text { yes } \\
545\end{array}$ & $\begin{array}{l}\text { yes } \\
450\end{array}$ \\
\hline Log likelihood & $1,860.02$ & $1,867.71$ & $1,627.73$ \\
\hline
\end{tabular}

Note: See the notes to tables 3.2 and 3.3. "Red tape" equal to 11 minus the corresponding $\mathrm{BI}$ index, so that larger numbers mean more red tape.

\subsection{Concluding Remarks}

This paper investigates the effects of corruption, tax rates, and capital on the ability of host countries to attract foreign direct investment. It reaches two main conclusions. First, in isolation, each of the three factors has a negative effect on inward investment: Countries with higher tax rates, or more corruption, or more restrictions on capital account transactions, attract less foreign investment, all other things being equal. 
Second, the three factors could interact with each other and produce a complicated aggregate effect. In particular, it is sometimes argued that corruption may allow firms to evade excessive taxation and severe capital account restrictions (the grease payment argument) and thereby actually encourage investment. In the data, there is no support for the view that taxation has a smaller negative effect on foreign investment in a more corrupt host country. With regard to capital controls, there is some support for the view that corruption may reduce the burden of severe capital controls when a ten-step measure of the control is used. However, this result is not robust to the use of dummy variables to separate high corruption from low corruption, and severe capital controls from mild capital controls. Hence, the data do not support the efficient grease payments argument.

In short, the evidence indicates that taxes and capital controls hinder foreign investment. Bureaucratic corruption adds rather than relieves the burdens that they impose.

\section{References}

Desai, Mihir, and James R. Hines Jr. 1996. "Basket" cases: International joint ventures after the Tax Reform Act of 1986. NBER Working Paper no. 5755. Cambridge, Mass.: National Bureau of Economic Research, September.

Feldstein, Marin, James R. Hines Jr., and R. Glenn Hubbard. 1995. The effects of taxation on multinational corporations. Chicago: University of Chicago Press.

Frankel, Jeffrey, Ernesto Stein, and Shang-Jin Wei. 1995. Trading blocs and the Americas: The natural, the unnatural, and the super-natural. Journal of Development Economics 47 (June): 61-95.

Hines, James R., Jr. 1995. Forbidden payment: Foreign bribery and American business after 1977. NBER Working Paper no. 5266. Cambridge, Mass.: National Bureau of Economic Research, September.

1996. Capital controls and foreign direct investment.

Huntington, Samuel P. 1968. Political order in changing societies. New Haven: Yale University Press.

Kaufmann, Daniel, and Shang-Jin Wei. 1999. Does "grease money" speed up the wheels of commerce? NBER Working Paper no. 7093. Cambridge, Mass.: National Bureau of Economic Research, April.

Leff, Nathaniel H. 1964. Economic development through bureaucratic corruption. American Behavior Scientist 8 (2): 8-14.

Lui, Francis. 1985. A equilibrium queuing model of bribery. Journal of Political Economy 93 (4): 760-81.

Mauro, Paolo. 1995. Corruption and growth. Quarterly Journal of Economics 110: $681-712$.

Organization for Economic Cooperation and Development (OECD). 1991. International direct investment statistics yearbook. Paris: OECD.

Price Waterhouse. 1990. Information guide, for various countries. New York: Price Waterhouse. 
Rauch, James. 1996. Networks versus markets in international trade. NBER Working Paper no. 5617. Cambridge, Mass.: National Bureau of Economic Research, June.

Wei, Shang-Jin. 1997. Why is corruption so much more taxing than tax? Arbitrariness Kills. NBER Working Paper no. 6255. Cambridge, Mass.: National Bureau of Economic Research, November.

2000. How taxing is corruption on international investors? Review of Economics and Statistics 82 (1): 1-11.

World Economic Forum. 1997. Global competitiveness report. Geneva, Switzerland: World Economic Forum.

\section{Comment Bernard Yeung}

The objective of this paper is to determine whether taxes, capital controls, and corruption discourage inward foreign direct investment. More importantly, the paper attempts to check whether corruption will serve as a "grease payment" that mitigates the negative effect of tax and capital controls in attracting foreign direct investment. The main results are that taxes, capital controls, and corruption all discourage inward foreign direct investment and that the grease payment effect is absent.

In my opinion, the empirical attempt is timely and important. Economics is an applied science; we need solid empirical results to back up our theories and thus to strengthen our understanding of the world. The research design in the paper is rather clever-it will allow the data to speak up if corruption has a grease payment effect. Praise to the author.

The empirical results in the paper are appealing. As an economist trained in North America, I am biased against corruption and genuinely would hope that the results are as credible as they can be. Therefore, I would like to point out some needed data improvements to make the results more credible.

The dependent variable is 1991 inward foreign direct investment from fourteen countries (including the largest industrialized countries, in terms of outward direct investment) to forty-five countries and is obtained from an OECD database. Different countries have different definitions for foreign direct investment. For example, the United States uses 10 percent ownership for both inward and outward foreign direct investment, whereas Japan uses 25-50 percent for inward and 10 percent for outward. Hence, what is counted as inward foreign direct investment in one country may not be counted as such in another. To the extent that countries with more capital controls have a higher ownership requirement to classify inward

Bernard Yeung is the Abraham Krasnoff Professor of Global Business at New York University's Stern School of Business. 
investment as "direct," a systematic bias may exist in the data. I have a hunch that this bias may not be empirically important. Still, it would be useful to check how the OECD data are compiled and whether the above problem exists in a material manner.

The independent variables have more problems. Let me start with the tax variable. In the paper, the tax variable is defined as the lower of two numbers: "the statutory marginal tax rate on foreign corporations as reported by Price Waterhouse (1990), or the actual average tax rate paid by the foreign subsidiaries of U.S. firms in that country." Actual tax paid is an endogenous variable likely affected by corruption. Apparently, the author believes that American firms are mostly honest and that they follow tax codes strictly, so that their tax rates are representative of the actual tax rates. Some would have doubts. One wonders why the author does not use the Price Waterhouse reported rates only.

The capital control data are based on 1980-83 surveys. Capital controls changed quite a bit from 1983 to 1991. In particular, many Asian countries relaxed their capital controls and rolled out a red carpet for foreign investment. The historical survey data would not be irrelevant as long as foreign direct investment behavior did not change much in the eighties. However, to the extent that foreign direct investment surged in the eighties, the author should find a set of survey data closer to 1991. Similarly, although corruption likely changes less rapidly than capital controls, it would be nice to have more current corruption data.

The most interesting result of the paper is that a grease payment effect does not exist. The grease payment effect is that companies can bribe government officers to reduce the damage of taxes and capital controls on their businesses. As a consequence, taxes and capital controls have less negative effect in attracting foreign direct investment. The cross terms between "corruption" and "tax" and between "corruption" and "capital control" are supposed to capture that - that the presence of a grease payment effect will lead to positive and significant cross terms. Note that the design suggests that the corruption survey data should capture only "government corruption." The corruption survey data used capture something more general: "the degree to which business transactions involve corruption or questionable payments." While the more general survey data are likely highly correlated with "government corruption," the more precise survey variable is known to exist.

Overall, this paper attempts to show empirical evidence of the idea that taxes, capital controls, and corruption discourage foreign direct investment and that the grease payment effect does not exist. The results are intuitively believable. I doubt the suggested data improvements would change the results. Rather, they should strengthen their credibility. 